\title{
The Poetic Bliss of the Re-described Reality: Wallace Stevens: Poetry, Philosophy, and the Figurative Language
}

The article addresses the issue of the intimate but troublesome liaison between philosophy and literature-referred to in scholarship as "the ancient quarrel between poets and philosophers." Its aim is double-fold. First, it traces the interweaving paths of philosophical and literary discourse on the example of Wallace Stevens's oeuvre. It demonstrates that this great American modernist advocates a clear distinction between poetry and philosophy on the one hand, but draws on and dramatizes philosophical ideas in his poems on the other. The vexing character of his poetic works exemplifies the convoluted and inescapable connections between philosophy and poetry. Second, it discusses various approaches to metaphor, highlighting Stevens's inimitable take on it. The diverse ways of tackling metaphorical language cognize metaphor's re-descriptive and reconfiguring character. They embrace e.g., Stevens's concept of metaphor as metamorphosis, or as "resemblance rather than imitation." The to date interpretations of Stevens's poetry in the light of a whole host of philosophies yield important insights into the meaningful interconnections between poetry and philosophy. However, rather than offering another interpretation of his poems from a given philosophical angle, the versatile voices presented here interrogate what poetry consists in.

Keywords: metaphor, philosophy, poetry, re-configuration, Wallace Stevens. 
Wallace Stevens: Poetry, Philosophy, and the Figurative Language is a groundbreaking collection of essays investigating the output of one of America's most highly acclaimed twentieth-century poets. The abstract poetry of Wallace Stevens, which eschews any easy classifications, continues to attract new and versatile critical approaches, of which the present volume is a superb example. The poet's preoccupation with reality as blending with creative imagination led to works whose profound insightfulness into "what is" inspires us to interrogate both their philosophical tenor, as well as their affinities with the philosophical thought they seem to contain. As the editors themselves stress, Stevens's poetry has to date been interpreted through the lens of a whole panoply of philosophers: Edmund Husserl, Martin Heidegger, Immanuel Kant, Friedrich Nietzsche, Jacques Derrida, William James and George Santayana. Interestingly, instead of offering another interpretation of Stevens's oewore in the light of a particular philosophy, the present volume proposes a perspicacious exploration into the very nature of poetry.

The division of the book into two parts is dictated by a clear differentiation between issues of a general nature and the more detailed analysis of Stevens's use of figurative language. Part One partakes in a discussion of the nourishing connections between poetry and philosophy as evinced in Stevens's works. This far more-inclusive attitude to his poetic and prose writings shifts in Part Two to a nuanced examination of one concept in particular. Here, the essays are grouped around various understandings of the phenomenon of metaphor. Placing Stevens within a wider modernist artistic and philosophical milieu, the editors/authors of this volume posit that he is not to be pigeonholed too hastily simply as a philosophizing poet, but much more profoundly as a poet whose stanzas are expressive of the intimate interrelationship of poetry and philosophical thought. Asserting this, they endorse Charles Altieri's seminal words that Stevens's poetry "gives a pulse to philosophical thinking" (38). The admirable, intricate and debatable (as regards the issue of its philosophical intent) character of Stevens's poems is already signaled in the Introduction, where we read that Stevens "imbibed an intuitive sense of how the being of the poem as a beautiful aesthetic object corresponds with and thrives in close proximity to the movement of thought" (12). The question of the being of the poem seems to be the guiding thread of the book's miscellaneous contributions. They demonstrate that Stevens's keen interest in reality and the interrelations between reality and imagination, which we commonly deem philosophical matters, bespeaks the reflective nature of his works.

In Part One's opening essay, Charles Altieri argues that Stevens's poem "Of Modern Poetry" is a dramatization of the powers of the human mind, as well as an intriguing model of Hegel's concept of inner sensuousness. As the author reveals, inner sensuousness "refers to how 
states of self-consciousness are embodied as conditions of feeling rooted in one's sense of one's own subjective relations to an object world" (27). Altieri elucidates the fact that Stevens's recourse to inner sensuousness was necessitated by an attempt to use a language appropriate to express "states of self-consciousness of one's own constructive acts" (28). According to the critic, addressing those dimensions of creation which are not confined to an individual subject, Stevens finds a pathway which affords the transition from the personal to the transpersonal. One might venture the thesis that Stevens's poem, framed with two similar sentences evocative of the contiguity between poetic activity and the human being's intellectual prowess - "The poem of the mind" and "The poem of the act of the mind," as well as Altieri's exhaustive meditation on it - instantiate a hermeneutic search for understanding. Ending up with a whole host of questions, this essay proves that Stevens's poetry can be understood as a proxy of philosophical pondering. Entertaining a similar thought to Czesław Miłosz's idea of "the invincible mind," encapsulated in his 1968 poem "Incantation" (210), Stevens's poetry heralds a human being's ability to traverse that which has not been dreamed of.

The next essay by Wit Pietrzak, "They Will Get it Straight One Day at the Sorbonne": Wallace Stevens's Intimidating Thesis," involves us in a differently angled but equally exhilarating dialogue between poetry and philosophy. The author reflects on Simon Critchley's Heideggerian reading of Stevens, of which he is critical. In the later part of the essay, he also discusses the influence of Santayana's philosophy on Stevens's poetry. Exploring the edgy (dis)connectivity between poetry and philosophy, the author highlights Stevens's propounding of the chasm between the two disciplines, and elaborates his skepticism about associating "with philosophy of whatever ilk" (34) The controversy which shrouds the pervasive perception of Stevens's poetry as philosophical and his own denial of having much to do with philosophy is straightened out via a detailed study of his poems ("Notes toward a Supreme Fiction," in particular), as well as his prose works. Apparently, Stevens's own provocative words"Perhaps it is of more value to infuriate philosophers than to go along with them" (34)—can be seen to shed light on the perturbed liaison.

Pietrzak's reflection clearly shows that it is creative imagination which constitutes a portentous terrain for the perichoretic encounters between poetry and philosophy. He muses on Stevens's understanding of imagination and philosophy thus:

what Stevens desires is "to regard imagination as metaphysics," which means "to think of it as part of life, and to think of it as part of life is to realize the extent of artifice" (NA: 140). If anything, Stevens wanted 
philosophy to leave logic and its investigations into the truth content of propositions in favour of explorations of the illogicalities of imagination, or what a decade earlier he had called "the irrational element in poetry" (see Stevens, 1989/90, 226). (34)

Stevens's inimitable take on imagination is what persuades us to think that, for him, the real and the imagined feed one another or even seem to be co-substantial. Furthermore, his appeal for philosophy's engagement with the "illogicalities of imagination" indicates that he purports to negotiate between the terse boundaries of what we deem reality and imagination.

As already mentioned, probing the perplexing connection between poetry and philosophy, Pietrzak expresses his distrust of Critchley's deployment of a Heideggerian perspective in an analysis of Stevens's poetry (35-37). One of the main points that Critchley seems to miss, according to Pietrzak, is that for Stevens "poetry is not just a way of uttering the perception of reality but of shaping ever new perceptions that derive not so much from a hard reality but from prior poetic utterances" (36). Thus, we can gather that Stevens's stance on poetry as participating in a meaningful dialogue with the cache of previous poetic utterances expands the view of what reality is. Pietrzak's critique of Critchley's stance becomes even more explicit in the later part of the essay, in which he writes: "Quick to derive Heideggerian motifs from Stevens's idiosyncrasies, Critchley ventriloquizes "An Ordinary Evening in New Haven," saying that "words of the world are the life of the world and poetry is the highest use of those words" $(2005,54) ”(36)$.

However, the disavowal of Critchley's viewpoint does not exhaust this essay's examination of the philosophical aptitude of Stevens's poetry. If his poetic works can be viewed as elucidating philosophical ideas, the following quotation from Pietrzak's essay, which is also an endorsement of Altieri's reflection, takes us to the very heart of poetry and philosophy belonging together:
"Stevens gives a pulse to philosophical thinking . . . by inviting his audience to share the pleasure and the excitement of states in which we momentarily resolve tensions and manage to change our angle of vision." This change of angle of vision, the Stevensian "new bearing in a new reality," results, for Altieri, in the creation of values "as small ecstasies where managing to correlate mind and world affords charged moment in which one feels at home in imaginative activity" (Altieri 2013, 7). (38)

Thus, we may infer, following Pietrzak and Altieri, that the epiphanic moments disclosing the real in Stevens's poetry are also the locus of the philosophical unveiling of reality. 
Karl-Friedrich Kiesow's "The Kinship of Poetry and Philosophy. Reflections on W. Stevens and P. Weiss," is a deft reinvigoration of the discussion of the affinities between poetry and philosophy, instantiated via a close examination of the intellectual relationship between Stevens, the poet, and Weiss, the philosopher. Kiesow avers that the Stevensian poetic vision, which saw human dignity as having the potential to replace traditional faith, is a stance endorsed in Weiss's philosophy. Through a detailed analysis of "Men Made out of Words," "Three Philosophical Poets," "The Anatomy of Monotony" and Stevens's other poems, the critic claims that the poet conceives a particular brand of cosmology. The intersections between the two intellectuals, encompass much more, though. Inspired by Duns Scotus, Weiss shifts his interest from the idea of a general man to an individual human being. His initial anthropology of the human being as a fallible and imperfect creature transforms into an ardent interest in the human as a capable being. As Kiesow argues, the latter attitude coalesces with Stevens's concepts of the "central man," the "human globe," and the "impossible possible philosopher's man" (52), as well as the idea of a human person stranded between constancy and diversity. The final sentences of this essay emphasize that the conviction of the ambiguous nature of the interconnections between poetry and philosophy is shared by both Stevens and Weiss.

In the last essay of Part One: "Reality Is Not a Solid. Poetic Transfigurations of Stevens' Fluid Concept of Reality,” Jakub Mácha addresses the concept of the fluidity of reality in Stevens's poetic work. This delightfully meticulous study of the many realities that Stevens's poetry embodies: "initial reality (the external world of the common sense), imagined reality (a fiction, a product of one's mind), final reality (the object of a philosopher's and a poet's search) and total reality (the sum of all realities, Being)" (61), through its commitment to the poet's contemplation of Being, is also, finally, an acknowledgement of the value of employing Heidegger's perspective to interpret Stevensian poetic output. Whilst perhaps an unintended result, it is exceptionally meaningful as from the outset Mácha situates himself contra Simon Critchley (a zealous Heideggerian critic). Tracing the cornerstones of Stevens's poetics, Mácha's unrivalled precis of the many realities his poetry captures also embraces a study of the interlocking character of reality and imagination accomplished via an investigation of the analogies between the poet in question and Schelling. Pinpointing the closeness between Schelling's and Stevens's notions of imagination and reason, Mácha convinces us that Stevensian poetry can be viewed as an apt elucidation of Shelling's transcendental idealism (67). Expanding its already wide-ranging scope, Mácha's compelling survey also refers to S. T. Coleridge's poetry-the 
critic notices the distinction between imagination and fancy that Stevens employs after Coleridge (70).

Part Two opens with Chris Genovesi's contribution: "Au Pays de la Métaphore: Wallace Stevens and Interaction Theory." Spanning an impressive assemblage of thinkers, from Aristotle, Kant, Locke and Hobbes, to Max Blank, Paul Ricœur and Carl R. Hausman, the essay tackles the issue of metaphor's capacity for creating meaning. This remarkably thorough account of the varied philosophical positions at play here culminates in a reflection on Stevens's definition of metaphor as metamorphosis. Genovesi makes it clear that the acquiescing of resemblance to the benefit of reality's transformation is the crux of Stevens's take on metaphor: "Through metaphor, reality is transformed and enhanced. It is made 'brilliant.' Importantly, Stevens notes that resemblance is a desire 'to enjoy reality' and that this desire is 'the desire for elegance' (Stevens 1960, 78)" (104). Although Genovesi does not allocate much space to Ricœur's philosophical interrogation of metaphorical language, this part of the essay seems to be outstandingly illuminative in terms of the transition element in Stevens's outlining of metaphor. Ricœur's in-depth analysis, hinging upon the word's etymology (meta-phora, "phora" meaning movement) (Ricœur 18), contributes to the conceptualization of metaphor as a vehicle taking us to a reconfigured reality. Genovesi's engaging explication of metaphor's transformative power demonstrates that the gist of its functioning lies in a capability to re-describe, reconfigure, and reshape our reality.

In "Resemblance and Identity in Wallace Stevens' Conception of Metaphor," Richmond Kwesi maintains that Stevens's concept of metaphor is predicated on resemblance rather than identity. He introduces us to Stevens's short but telling rendering of metaphor as "[c]reation of resemblance by the imagination" (113). Situating Kwesi's essay at this point in the book is definitely a well-grounded move. Kwesi picks up where Genovesi, the previous contributor, left off. For Kwesi, the Stevensian conceptualization of metaphor as metamorphosis offers a possibility to grasp the movement which occurs in it. The interplay of resemblance and identity in metaphor that Stevens advocates is spelled out by Kwesi in the following manner: "rather than thinking of the 'is' (identity) of metaphor as an 'as' (resemblance), for Stevens, the 'as' (resemblance) of metaphor metamorphosize into an 'is' (identity)" (113). Significantly, the critic highlights Stevens's proclivity to include unlikeness and dissimilarity as legitimate constituents of metaphor, and explicates their import in the following way:

Stevens' emphasis on the creation of resemblances by the imagination locates metaphor within the creative industry: metaphor is a cognitive phenomenon. As much as metaphor trades on similarities, often it is the 
case that metaphor also reflects dissimilarities between things, or allows us to "create similarities" (Black 1962: 37) where none has hitherto been recognized. (118)

In this thorough investigation of metaphor's "resourcefulness," Kwesi refers to numerous critics, including Max Black, David Punter and Dawn G. Blasko. Inasmuch as his account stresses the poet's avowal of metaphor's innovatory power, it does justice to his passion for metaphor's freedom. He writes that, for Stevens, "poetry does not proscribe certain metaphorical expressions; poetry does not set out rules to distinguish the use and abuses of metaphors; poetry does not determine the aptness and correctness of metaphors" (119).

Ondrej Beran's essay, entitled "Metaphor as That Which Makes us See," sensitizes us to an apparently facile but exceptionally significant truth. Following Iris Murdoch's conviction that "art awakens us to the reality we tend to overlook, engaged as we are with our fantasies" (139), the critic asserts Stevens's conception of metaphor as that which aligns the seemingly unlikely and invites to see differently. Undoubtedly, the newness of seeing is the product of imagination, and thus the creative process that is triggered expands our understanding of reality. The freshness of seeing, which is accomplished through metaphorical language, alerts us to the wholly unexpected. The salient contention of seeing-as (seeing anew) is also prompted here by recourse to Wittgenstein. Beran stresses metaphor's potential for rendering that which is overlooked, and for making us marvel at the new connections expressive of resemblance rather than imitation: "Metaphor then consists in finding, to put it in Wittgenstein's (1980: I., $\$ 72,73$ ) words, a 'fitting word' (zutreffendes Wort) that would convey the import to a person who doesn't see and that would make her see" (151). The fittingness conveys the capacity of metaphor to transcend the barrier of the cursory, in which the play of imagination begets a new, but also more adequate, comprehension of reality.

The book is rounded off with Kacper Bartczak's "Wallace Stevens's Spirituality of the Metaphorical Inhabitation of the World." This essay scrutinizes the interconnections between Stevens's poetic activity as an exploration of reality and his attitude to religion. Bartczak reminds us that Stevens's poetics was "developed in part as a response to a religious crisis that he experienced as a young man, more or less at the beginning of his poetic road" (159). The poet's waning belief in a religious explanation of the world, viewed as a meaningful catalyst for the creation of poetry, inspires Bartczak to interrogate the Stevensian take on metaphor as "a space of epistemological and spiritual risk" (160). The poet's own words, "Men feel that the imagination is the next greatest power to faith" (161), illuminate 
the import of his shift from the doxa of traditional religion to poetry's creative propensity. However, the reshaped religious motifs can be traced, for instance, in Stevens's poem "The Rock," in which, as Bartczak explains, "the initial examination of the ruin leads to a resuscitation of a power that is central to any religious project and is perceived as a renewable resource" (166). With the backdrop of Daniel Davidson's critical reflection, encapsulated in his "What Metaphor Means," Bartczak makes the inseparability of spirituality and metaphorical language in Stevens clear and engrossing. He writes:

Let us pause at the "new account" trope. This kind of knowledge is at the heart of Stevens's achieved synthesis of rhetoric and spirituality: it is a regained, actively developed sense of one's real that is inseparable from the rhetorical force with which the poem shifts the earlier cognitive structures. For Stevens, to be alive means to inhabit one's space through a rhetorically active gesture of re-description. (168)

Employing diverse critical voices-Davidson, Rorty, Wheeler, to mention just a few-the book's final paper deepens the analysis of metaphor conducted here. It manifests Part Two's extensive and coherent inquest into what constitutes metaphorical language.

In lieu of a conclusion, one must emphasize that Wallace Stevens: Poetry, Philosophy, and the Figurative Language is an enriching intellectual journey into the intersections and cross-fertilizations of poetry and philosophy. This volume provides a convincing account of the two sides of the issue of the proximity between poetic and philosophical discourse in Stevens's works. Despite its profound interest in the matters of reality, human beings and Being, on the basis of which Stevens's poetry might be viewed as philosophically oriented and suffused, the poet himself advocates that a stark distinction be made between poetry and philosophy. On the other hand, the various critical perspectives presented here demonstrate the distinctly philosophical character of his poetic works, even if avowing their vexing genesis and telos.

The philosophically and poetically underwritten standpointRicœur's definition of metaphor as "a microcosm of poetic discourse" (104) which can be seen as Stevens's poetic dictum, too-provides a noteworthy transition between the two parts of the volume. The centrality of metaphor to Stevens's understanding of poetry prompts a continuous exploration of the nooks and crannies of metaphor's phenomenal nature. Riveting in its sweep and meticulous in its survey, Part Two extends the usual spectrum of the linguistic research into metaphor as a rhetoric device, by bringing phenomenological and hermeneutic 
approaches into play. This impressive and capacious inquiry illustrates the riches of the imaginative potential of metaphor in an accessible way, as well as the vicissitudes of researching it.

Unquestionably, the essays selected for the two parts of the book are prescient contributions to Stevensian scholarship, and, by extension, to an ongoing debate about the poetry and philosophy belonging together. Inspiring us to probe deeply into Stevens's poems, and to discover and rediscover the beauty and fullness of metaphorical language, Wallace Stevens: Poetry, Philosophy, and the Figurative Language is indispensable reading for anyone drawn to poetry's captivating ways of unveiling unexpected realities.

\section{Works CiTED}

Altieri, Charles. Wallace Stevens and the Demands of Modernity: Toward a Phenomenology of Value. New York: Cornell UP, 2013. Print.

Bartczak, Kacper, and Jakub Mácha, eds. Wallace Stevens: Poetry, Philosopby, and the Figurative Language. Studies in Philosophy of Language and Linguistics 13. Berlin: Peter Lang, 2018. Print. https://doi.org/10.3726/ b14736

Black, Max.Modelsand Metaphors: Studies in Languageand Philosophy. Ithaca, NY: Cornell UP, 1962. Print. https://doi.org/10.7591/9781501741326

Blasko, Dawn G. "Only the Tip of the Iceberg: Who Understands What About Metaphor." Journal of Pragmatics 31 (1999): 1675-83. Print. https://doi.org/10.1016/S0378-2166(99)00009-0

Critchley, Simon. Things Merely Are. London: Routledge, 2005. Print.

Miłosz, Czesław. "Incantation." The Collected Poems 1931-1987. New York: Ecco, 1988. 210. Print.

Punter, David. Metaphor. London: Routledge, 2007. Print.

Ricour, Paul. The Rule of Metaphor: The Creation of Meaning in Language. Trans. Robert Czerny, Kathleen McLaughlin and John Costello, SJ. London: Routledge, 2004. Print. https://doi. org/10.4324/9780203426616

Stevens, Wallace. Collected Poems. New York: A. A. Knopf, 1954. Print.

Stevens, Wallace. Collected Poetry and Prose. New York: Library of America, 1997. Print.

Stevens, Wallace. Opus Posthumous. Ed. Milton J. Bates. New York/ London: A. A. Knopf, 1989/1990. Print.

Stevens, Wallace. The Necessary Angel. Essays on Reality and Imagination. New York: A. A. Knopf, 1951. Print.

Wittgenstein, Ludwig. Remarks on the Philosophy of Psychology. Oxford: Basil Blackwell, 1980. Print. 
Małgorzata Hołda, PhD in British literature (Nicolaus Copernicus University in Torun 2006), $\mathrm{PhD}$ in philosophy with distinction for dissertation: Paul Ricour's Concept of Subjectivity and the Postmodern Claim of the Death of the Subject (The Pontifical University of John Paul II in Krakow), published with Ignatianum University Press, 2018. She has been Junior Associate Fellow of the International Institute for Hermeneutics in Freiburg since 2014. She conducts interdisciplinary research in Anglophone literature and philosophy, exploring topics within modern and postmodern novel, philological and philosophical hermeneutics, phenomenology and postmodern philosophy. Her most recent research concerns Virginia Woolf's and Hans-Georg Gadamer's hermeneutics of the beautiful, as well as Paul Ricœur's hermeneutics of l'homme capable, and subjectivity. Her publications foster an understanding of hermeneutics as a mode of being.

ORCID: 0000-0003-3772-6297

malgorzata.holda@uni..lodz.pl 